\title{
Balint syndrome in anti-NMDA receptor encephalitis
}

Aude Metzger, MD, PhD, Laure Pisella, PhD, Alain Vighetto, MD, PhD, Bastien Joubert, MD, Jérôme Honnorat, $\mathrm{MD}$, PhD, Caroline Tilikete, $\mathrm{MD}, \mathrm{PhD}$, and Virginie Desestret, $\mathrm{MD}, \mathrm{PhD}$

Neurol Neuroimmunol Neuroinflamm 2019;6:e532. doi:10.1212/NXI.0000000000000532

We report 2 cases of NMDA receptor (NMDAR) encephalitis with classic signs and symptoms of encephalitis, but in whom Balint syndrome was a predominant manifestation in the evolution of the disease.

Patient 1, a 24-year-old woman, presented initially with catatonia, mutism, unusual anxiety, and generalized epileptic seizures. She received 3 months of intensive care. She had no psychosis, no movement disorders, no sleep disturbance, or dysautonomia. Cerebral MRI was normal. Based on a large workup (table) and positivity of CSF anti-NMDAR antibodies, a diagnosis of NMDAR encephalitis was made, and she was accordingly treated for encephalitis and seizures (table). No teratoma was detected. One year after disease onset, neuropsychological assessment found deficits in executive functions (working memory, planning, and mental flexibility), constructive apraxia, and left spatial neglect; Balint syndrome was not assessed at this time. She was evaluated again 2 years after disease onset because of visual complaints, such as misreaching when grasping objects and difficulty to judge distances. Ophthalmologic examination and visual field were normal. Neurologic examination highlighted difficulties to reach and grasp a pen introduced in the patient's peripheral visual fields related to bilateral optic ataxia ${ }^{1}$; lateralized spatial attention disorder attested by a rightward bias in manual line bisection and left omissions related to left hemineglect; and partial descriptions of complex pictures and embedded shapes, inability to detect the contour of dotted lines and to perform visual labyrinth tests, and inability to enumerate dots with a revisiting phenomenon consistent with simultanagnosia. ${ }^{2}$ Eye movements were normal. A full Balint syndrome was therefore diagnosed on the association of optic ataxia, psychic paralysis of gaze (simultanagnosia), and lateralized disorder of attention (left hemineglect). ${ }^{3}$ At this time, cerebral MRI remained normal, 18 fluorodeoxyglucose PET $\left({ }^{18} \mathrm{~F}\right.$-FDG PET/CT $)$ found a mild left fronto-temporoparietal and insular hypometabolism, and EEG found diffuse posterior slow waves without epileptiform abnormalities. She was treated with 2 new infusions of rituximab. Anticonvulsants were not modified.

Patient 2, a 19-year-old woman, presented with severe limb apraxia and aphasia, behavioral disorders such as emotional lability and psychomotor slowing, associated with signs of Balint syndrome. The patient had no movement disorders, no epileptic seizure, sleep disturbance, or dysautonomia. Based on a large workup (table) and the positivity of CSF anti-NMDAR antibodies, a diagnosis of NMDAR encephalitis was made, and she was accordingly treated (table). No teratoma was found. At this time, cerebral MRI was normal, ${ }^{18}$ F-FDG PET/CT showed left temporo-occipito-parietal and bilateral insular hypermetabolism, and EEG found bilateral occipital and parietal slow waves without epileptiform abnormalities. She was reevaluated 2 months after diagnosis at a rehabilitation center owing to the persistence of visual symptoms after recovery from aphasia and apraxia. Ophthalmologic examination and visual

\author{
Correspondence \\ Dr. Metzger \\ aude.metzger@chu-lyon.fr
}


Table Description of patients

\begin{tabular}{|c|c|c|}
\hline & Patient 1 & Patient 2 \\
\hline Age & 24 years & 19 years \\
\hline \multirow{3}{*}{$\begin{array}{l}\text { Initial clinical } \\
\text { presentation }\end{array}$} & Aphasia & Apraxia \\
\hline & Catatonia & Aphasia \\
\hline & Generalized seizures & $\begin{array}{l}\text { Behavioral disorders (emotional liability and psychomotor } \\
\text { slowing) }\end{array}$ \\
\hline \multirow[t]{10}{*}{ CSF analysis } & At disease onset: & At disease onset: \\
\hline & 19 WBC & $12 \mathrm{WBC}$ \\
\hline & Normal protein level & Normal protein level \\
\hline & Oligoclonal bands & Oligoclonal bands \\
\hline & Positive anti-NMDAR antibodies in serum and CSF & Positive anti-NMDAR antibodies in CSF \\
\hline & Two years after disease onset: & Two months after disease onset: \\
\hline & Normal cell count & Normal cell count \\
\hline & Normal protein concentration & Normal protein concentration \\
\hline & No oligoclonal bands & No oligoclonal bands \\
\hline & Positive anti-NMDAR antibodies in CSF & Positive anti-NMDAR antibodies in CSF \\
\hline \multirow[t]{6}{*}{ Treatment } & Methylprednisolone $1,000 \mathrm{mg}$ daily for 5 days & Prednisolone $180 \mathrm{mg}$ daily for 1 month \\
\hline & IV immunoglobulin (2 courses, $0.4 \mathrm{~g} / \mathrm{kg}$ daily for 5 days) & IV immunoglobulin (1 course, $0.4 \mathrm{~g} / \mathrm{kg}$ daily for 5 days) \\
\hline & Rituximab (1,000 mg per infusion, 4 infusions) & Rituximab (1,000 mg per infusion, 2 infusions) \\
\hline & Cyclophosphamide (600 mg/m²/infusion, 9 infusions) & Cyclophosphamide (600 mg/m², 5 infusions) \\
\hline & Levetiracetam 1500 mg per day & \\
\hline & Lacosamide 250 mg per day & \\
\hline Follow-up & 26 months & 6 months \\
\hline \multirow{11}{*}{$\begin{array}{l}\text { Balint syndrome } \\
\text { assessment }^{2}\end{array}$} & Two years after disease onset: & Two months after disease onset: \\
\hline & Bilateral optic ataxia (left > right) & Bilateral optic ataxia \\
\hline & Simultanagnosia & Simultanagnosia \\
\hline & Inability to identify superimposed figure identification & Inability to identify superimposed figure identification \\
\hline & Inability to perform visual labyrinth tests & Inability to perform visual labyrinth tests \\
\hline & Inability to identify the contour of dotted lines & Inability to identify the contour of dotted lines \\
\hline & Partial description of a complex picture & Partial description of a complex picture \\
\hline & $\begin{array}{l}\text { Erroneous counting with overestimations of the number of } \\
\text { dots }\end{array}$ & $\begin{array}{l}\text { Erroneous counting with underestimations of the number of } \\
\text { dots }\end{array}$ \\
\hline & $\begin{array}{l}\text { Elementary visual-perceptual impairment: length } \\
\text { comparison, size comparison, angle comparison task, } \\
\text { midline localization, comparison of dot position, and dot } \\
\text { position among distractors research. Total: } 58 / 72 \text { (impaired) }\end{array}$ & $\begin{array}{l}\text { Elementary visual-perceptual impairment: length } \\
\text { comparison, size comparison, angle comparison task, } \\
\text { midline localization, comparison of dot position, and dot } \\
\text { position among distractors research). Total: } 52 / 72 \text { (impaired) }\end{array}$ \\
\hline & Left visual neglect & Left visual neglect \\
\hline & $\begin{array}{l}\text { Systematic rightward bias at manual line bisection (mean } \\
\text { deviation: } 0.8 \mathrm{~cm} \text { ) }\end{array}$ & $\begin{array}{l}\text { Systematic rightward bias at manual line bisection (mean } \\
\text { deviation: } 0.8 \mathrm{~cm} \text { ) }\end{array}$ \\
\hline
\end{tabular}


Table Description of patients (continued)

\begin{tabular}{lll}
\hline & Patient 1 & Patient 2 \\
\hline $\begin{array}{l}\text { Omission of elements displayed on the left side (map, } \\
\text { complex scene picture) } \\
\begin{array}{l}\text { neuropsychological } \\
\text { symptoms }\end{array}\end{array}$ & One year after disease onset: & $\begin{array}{l}\text { Omission of elements displayed on the left side (map, } \\
\text { complex scene picture) }\end{array}$ \\
\hline & Constructive apraxia & One month after disease onset: \\
\hline $\begin{array}{l}\text { Working memory deficit (digit span and symbol digit } \\
\text { modalities test) }\end{array}$ & $\begin{array}{l}\text { Mild constructive apraxia } \\
\text { modalities test) }\end{array}$ \\
\hline & Limitation of cognitive flexibility (Trail Making Test) & \\
\hline
\end{tabular}

Abbreviations: NMDAR $=$ NMDA receptor; $\mathrm{WBC}=$ white blood cell.

field were normal. Full Balint syndrome was diagnosed on the association of optic ataxia, simultanagnosia, and lateralized disorder of attention (left hemineglect) (table). ${ }^{2,3}$ Eye movements were normal. Balint syndrome recovered over the next 4 months.

\section{Discussion}

These 2 cases show the occurrence of Balint syndrome, in addition to other symptoms, in NMDAR encephalitis. Balint princeps description included optic ataxia, psychic paralysis of gaze (now called simultanagnosia), and lateralized disorder of attention (left spatial neglect), as observed in our 2 patients. ${ }^{3}$ Oculomotor apraxia as described later in addition to the triad was not observed in our 2 patients.

Balint syndrome is a reliable marker of bilateral parieto-occipital dysfunction. Accordingly, posterior slow waves were observed on EEG in our 2 patients. Such posterior EEG abnormalities have been previously reported in NMDAR encephalitis. ${ }^{4}$

While in most vascular or degenerative Balint syndrome, bilateral parieto-occipital hypo metabolism is reported; metabolic imaging in our patients showed different patterns. Occipital hypometabolism has been highlighted in NMDAR encephalitis, but other patterns have been described, such as focal and lateralized hypo- or hypermetabolism. ${ }^{5}$ Furthermore, seizures and psychotropic treatment may also contribute to the metabolic pattern variability.

The pathophysiologic mechanisms leading to these clinical, EEG, and imaging changes remain unclear. They could involve a direct pathogenic role of anti-NMDAR antibodies leading to NMDAR internalization and a consecutive change in neuronal activity. ${ }^{6}$ They could also involve a thalamocortical disconnection, as such damage in connectivity has been identified among users of ketamine, an NMDAR antagonist. $^{7}$
Our clinical observations highlight that posterior tropism of functional and metabolic changes reported in NMDAR encephalitis ${ }^{4,5}$ can be symptomatic. Future studies are needed to assess the prevalence and pathophysiology of Balint syndrome in NMDAR encephalitis.

\section{Study funding}

No targeted funding reported.

\section{Disclosure}

A. Metzger, L. Pisella, A. Vighetto, and B. Joubert report no disclosures. J. Honnorat receives royalties from licensing fees to Athena Diagnostics, Euroimmun, and Ravo Diagnostika for a patent for the use of CV2/CRMP5 as diagnostic tests and received research support from CSL Behring France. C. Tilikete received travel funding and/or speaker honoraria from Santhera, Novartis, and Teva; served on the editorial boards of the Journal of Neuro-Ophthalmology, Frontiers in Neurology, and Neuro-ophthalmology; and receives publishing royalties from Elsevier Masson. V. Desestret reports no disclosures. Full disclosure form information provided by the authors is available with the full text of this article at Neurology.org/NN.

\section{Publication history}

Received by Neurology: Neuroimmunology \& Neuroinflammation July 2, 2018. Accepted in final form November 8, 2018.

\section{References}

1. Perenin MT, Vighetto A. Optic ataxia: a specific disruption in visuomotor mechanisms. I. Different aspects of the deficit in reaching for objects. Brain 1988;111(pt 3): 643-674.

2. Pisella LBD, Vighetto A. Combination of attentional and spatial working memory deficits in Balint-Holmes syndrome. Ann N Y Acad Sci 2015;1339:165-175.

3. Harvey M. Psychic paralysis of gaze, optic ataxia, and spatial disorder of attention. Cogn Neuropsychol 1995;12:265-281.

4. Goldberg EM, Taub KS, Kessler SK, Abend NS. Anti-NMDA receptor encephalitis presenting with focal non-convulsive status epilepticus in a child. 2011;42:188-190.

5. Probasco JC, Solnes L, Nalluri A, et al. Decreased occipital lobe metabolism by FDGPET/CT: an anti-NMDA receptor encephalitis biomarker. Neurol Neuroimmunol Neuroinflamm 2018;5:e413.

6. Mikasova L, De Rossi P, Bouchet D, et al. Disrupted surface cross-talk between NMDA and Ephrin-B2 receptors in anti-NMDA encephalitis. Brain 2012;135(pt 5): $1606-1621$

7. Liao Y, Tang J, Liu J, et al. Decreased thalamocortical connectivity in chronic ketamine users. PLoS One 2016;11:e0167381. 
Appendix 1 Author contributions

\begin{tabular}{|c|c|c|c|}
\hline Name & Location & Role & Contribution \\
\hline $\begin{array}{l}\text { Aude Metzger, } \\
\text { MD, PhD }\end{array}$ & $\begin{array}{l}\text { Hôpital } \\
\text { neurologique Lyon } \\
\text { CRNL }\end{array}$ & Author & Drafting and revising the manuscript for intellectual content and clinical evaluation of patients \\
\hline $\begin{array}{l}\text { Laure Pisella, } \\
\text { PhD }\end{array}$ & CRNL & Author & $\begin{array}{l}\text { Major role in the acquisition of data, drafting and revising the manuscript for intellectual content, } \\
\text { analysis and interpretation of the data, and clinical evaluation of patients }\end{array}$ \\
\hline $\begin{array}{l}\text { Alain Vighetto, } \\
\text { MD, PhD }\end{array}$ & $\begin{array}{l}\text { Hôpital } \\
\text { neurologique Lyon }\end{array}$ & Author & $\begin{array}{l}\text { Major role in the acquisition of data, drafting and revising the manuscript for intellectual content, } \\
\text { analysis and interpretation of the data, and clinical evaluation of patients }\end{array}$ \\
\hline $\begin{array}{l}\text { Bastien Joubert, } \\
\text { MD }\end{array}$ & $\begin{array}{l}\text { Hôpital } \\
\text { neurologique Lyon }\end{array}$ & Author & Drafting and revising the manuscript for intellectual content \\
\hline $\begin{array}{l}\text { Jérôme } \\
\text { Honnorat, MD, } \\
\text { PhD }\end{array}$ & $\begin{array}{l}\text { Hôpital } \\
\text { neurologique Lyon }\end{array}$ & Author & Drafting and revising the manuscript for intellectual content \\
\hline $\begin{array}{l}\text { Caroline Tilikete, } \\
\text { MD, PhD }\end{array}$ & $\begin{array}{l}\text { Hôpital } \\
\text { neurologique Lyon, } \\
\text { CRNL }\end{array}$ & Author & $\begin{array}{l}\text { Design and conceptualization of the study, analysis and interpretation of the data, drafting and } \\
\text { revising the manuscript for intellectual content, and clinical evaluation of patients }\end{array}$ \\
\hline $\begin{array}{l}\text { Virginie } \\
\text { Desestret, MD, } \\
\text { PhD }\end{array}$ & $\begin{array}{l}\text { Hôpital } \\
\text { neurologique Lyon }\end{array}$ & Author & $\begin{array}{l}\text { Design and conceptualization of the study, analysis and interpretation of the data, and drafting } \\
\text { and revising the manuscript for intellectual content }\end{array}$ \\
\hline
\end{tabular}




\section{Neurology \\ Neuroimmunology \& Neuroinflammation}

Balint syndrome in anti-NMDA receptor encephalitis

Aude Metzger, Laure Pisella, Alain Vighetto, et al.

Neurol Neuroimmunol Neuroinflamm 2019;6;

DOI 10.1212/NXI.0000000000000532

This information is current as of December 13, 2018

\section{Updated Information \& Services}

References

Subspecialty Collections

Permissions \& Licensing

Reprints including high resolution figures, can be found at:

http://nn.neurology.org/content/6/1/e532.full.html

This article cites 6 articles, 0 of which you can access for free at: http://nn.neurology.org/content/6/1/e532.full.html\#\#ref-list-1

This article, along with others on similar topics, appears in the following collection(s):

Encephalitis

http://nn.neurology.org//cgi/collection/encephalitis

Neuropsychological assessment

http://nn.neurology.org//cgi/collection/neuropsychological_assessment

Visual processing

http://nn.neurology.org//cgi/collection/visual_processing

Information about reproducing this article in parts (figures,tables) or in its entirety can be found online at:

http://nn.neurology.org/misc/about.xhtml\#permissions

Information about ordering reprints can be found online:

http://nn.neurology.org/misc/addir.xhtml\#reprintsus

Neurol Neuroimmunol Neuroinflamm is an official journal of the American Academy of Neurology.

Published since April 2014, it is an open-access, online-only, continuous publication journal. Copyright

Copyright (C) 2018 The Author(s). Published by Wolters Kluwer Health, Inc. on behalf of the American

Academy of Neurology.. All rights reserved. Online ISSN: 2332-7812.

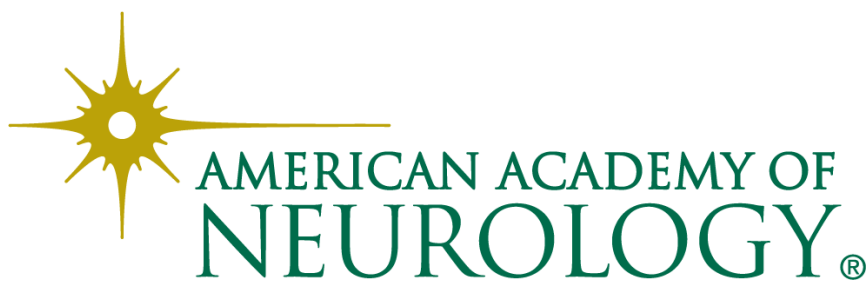

